\title{
AUDITORY BRAINSTEM RESPONSES IN HIGH-RISK NEONATES: 3 YEARS' EXPERIENCE AT AN ITALIAN HOSPITAL
}

\author{
Pietro Giordano, R.P. Ortore, A. D’Ecclesia, F. Cavalluzzo, E. Loria, C.L. Vigliaroli, R. Cocchi
}

ENT Unit, Casa Sollievo della Sofferenza Hospital, San Giovanni Rotondo, Italy

Corresponding author: Pietro Giordano, ENT Unit, Casa Sollievo della Sofferenza Hospital, San Giovanni Rotondo, Italy, e-mail: grdptr@unife.it

\begin{abstract}
Background: The World Health Organization (WHO) reported in 2013 that approximately 360 million people have disabling hearing loss, of which 32 million are children. A major consequence of hearing loss is a disability in communication: development of spoken language is often delayed in children with hearing loss, or absent in total deafness. Such children can benefit from a range of interventions such as hearing aids, cochlear implants, and educational and social support. Hearing screening can prevent the most severe consequences of hearing loss, but it is preferable first to consider populations with a high probability of developing hearing impairment. The present study assessed the incidence of hearing impairment through ABR in infants at high risk at Casa Sollievo della Sofferenza Hospital in southern Italy.
\end{abstract}

\begin{abstract}
Material and methods: The paper reports the results of auditory brain stem response (ABR) testing over a period of 3 years on infants born with a history of infantile respiratory distress syndrome (IRDS), otoacoustic emission failure at hearing screening, low birth-weight $(<1800 \mathrm{~g})$, family history of deafness, hyperbiluribinemia, premature birth, congenital infection (cytomegalovirus), or craniofacial anomalies.
\end{abstract}

Results: Of 549 infants tested, 469 (85.4\%) showed normal hearing, 51 (9.3\%) suffered mild hearing impairment, 6 (1.1\%) had moderate hearing impairment, $8(1.5 \%)$ had severe hearing loss, and $15(2.7 \%)$ failed to show any response at maximum intensity levels in both ears. For the hearing loss categories, the most important risk factors were found to be (in order of importance): craniofacial malformation, CMV infection, and familial factors.

Conclusions: ABR is an important clinical tool in the identification and quantification of hearing impairment. In neonatal screening it is preferable first to consider populations with a high probability of developing hearing losses.

Keywords: $\mathrm{ABR} \bullet$ auditory brainstem response $\bullet \mathrm{OAE} \bullet \mathrm{NICU} \bullet$ hearing loss

\section{POTENCIALES AUDITIVOS EVOCADOS DEL TRONCO CEREBRAL EN LOS RECIÉN NACIDOS DEL GRUPO DE ALTO RIESGO: ANÁLISIS EN BASE DEL ESTUDIO DE 3 AÑOS REALIZADO EN EL HOSPITAL EN ITALIA}

\section{Resumen}

Antecedentes: Según los datos de la Organización Mundial de Salud (WHO) del año 2013, unos 360 millones de personas sufre de pérdidas auditivas, de las cuales 32 millones son niños. La principal consecuencia de la pérdida auditiva son los problemas de comunicación: se observa el retraso en el desarrollo del habla en los niños con pérdida auditiva, o la falta del habla en los niños con sordera total. Estos niños pueden beneficiarse de diversas formas de apoyo, tales como audífonos, implantes cocleares, soportes científicos y apoyo social. Las pruebas de cribado del oído tienen el propósito de evitar consecuencias graves relacionadas con la pérdida auditiva. En el primer lugar se recomienda, sin embargo, determinar los grupos con el mayor riesgo de trastornos auditivos. El objetivo de este estudio ha sido la valoración de la presencia de trastornos auditivos mediante el registro de los potenciales auditivos evocados (ABR) en los recién nacidos del grupo de alto riesgo, ingresados en el Hospital Casa Sollievo della Sofferenza en la Italia del Sur.

Materiales y métodos: El estudio presenta los resultados de registros de los potenciales auditivos evocados obtenidos a lo largo de 3 años en los recién nacidos con el síndrome de dificultad respiratoria (IRDS), el resultado incorrecto de las pruebas del cribado a través del registro de las emisiones otoacústicas (OAE), bajo peso de nacimiento $(<1800 \mathrm{~g})$, hiperbilirubinemia, infecciones congénitas (citomegalovírus - CMV), deformidades cráneo-faciales, así como en los bebés prematuros y en los casos de aparición de la sordera en la familia.

Resultados: De los 549 recién nacidos examinados, en los $469(85,4 \%)$ se ha constatado una capacidad auditiva correcta, los $51(9,3 \%)$ tenían una pérdida auditiva leve, en otros 6 niños $(1,1 \%)$ se ha constatado la pérdida auditiva media y en otros 8 
$(1,5 \%)$ - una pérdida auditiva considerable; en 15 niños (2,7\%) no se ha registrado la respuesta ABR en ambos oídos. Para las susodichas categorías de las pérdidas auditivas, los mayores factores de riesgo (en orden empezando por el más popular), han sido: deformidades cráneo-faciales, infección con el virus CMV y los condicionantes genéticos.

Conclusiones: El estudio de los potenciales auditivos evocados del tronco encefálico es una herramienta clínica importante en la detección y determinación del grado de la pérdida auditiva. Durante la realización de las pruebas auditivas de cribado en los recién nacidos, en primer lugar se recomienda definir el grupo de personas con el mayor riesgo de tener deficiencias auditivas.

Palabras clave: estudio de respuestas auditivas del tronco encefálico (ARB) • emisión otoacústica (OAE) • unidad de cuidados intensivos para los recién nacidos (NICU) • pérdida auditiva.

\section{СЛУХОВЫЕ ВЫЗВАННЫЕ СТВОЛОМОЗГОВЫЕ ПОТЕНЦИАЛЫ У НОВОРОЖДЕННЫХ ИЗ ГРУППЫ ВЫСОКОГО РИСКА: АНАЛИЗ НА ОСНОВАНИИ З-ЛЕТНЕГО ИССЛЕДОВАНИЯ, ПРОВЕДЕННОГО В ИТАЛЬЯНСКОЙ БОЛЬНИЦЕ}

\section{Изложение}

Почва: Данные Всемирной Организации Здравоохранения (ВО3) с 2013 г. показывают, что почти 360 миллионов людей имеют нарушения слуха, в том числе 32 миллиона детей. Главным последствием тугоухости являются проблемы в коммуникации: наблюдается замедленное развитие разговорной речи у детей с тугоухостью, или ее отсутствие в случае полной глухоты. Эти дети могут пользоваться разными поддерживающими формами, например, слуховые аппараты, улитковые имплантаты, научные пособия и общественная поддержка. Целью скрининговых исследований слуха является предотвращение серьезных последствий, связанных с тугоухостью. Однако рекомендуется в первую очередь обнаружение популяций, особенно подверженных нарушениям слуха. Целью настоящего исследования была оценка наличия нарушений слуха с помощью регистрации слуховых вызванных потенциалов (ABR) у новорожденных из группы высокого риска, пребывающих в больнице Саsа Sollievo della Sofferenza на юге Италии.

Материалы и методы: Работа представляет результаты регистрации слуховых вызванных потенциалов на протяжении 3 лет у новорожденных с респираторным дистресс-синдромом (IRDS), неправильным результатом скринингового исследования с помощью регистрации отоакустической эмиссии (ОАЕ), низкой массой тела $(<1800$ г), гипербилирубинемией, врожденными инфекциями (цитомегаловирус - ЦМВ), черепно-лицевыми деформациями, у преждевременно рожденных детей и в случаях наличия глухоты в семье.

Результаты: Среди 549 исследованных новорожденных, у 469 (85,4\%) обнаружена нормальный слух, 51 99,3\%) имели легкую тугоухость, у $6(1,1 \%)$ обнаружена тугоухость средней, а у $8(1,5 \%)$ значительной степени, тогда как у 15 (2,7\%) не зарегистрирован двухсторонний ответ ABR. Для перечисленных категорий тугоухости, самыми важными угрожающими факторами (в порядке от самого частого) были: черепно-лицевые деформации, заражение ЦМВ и генетическая обусловленность.

Итоги: Исследование слуховых вызванных стволомозговых потенциалов - это важный клинический инструмент для обнаружения и определения степени тугоухости. Во время проведения скрининговых исследований у новорожденных, рекомендуется в первую очередь определить группы детей, особенно подверженных нарушениям слуха.

Ключевые слова: слуховые вызванные стволомозговые потенциалы (ABR) • отоакустическая эмиссия (OAE) • отделение интенсивной терапии для новорожденных (NICU) • тугоухость

\section{SŁUCHOWE POTENCJAŁY WYWOŁANE PNIA MÓZGU U NOWORODKÓW Z GRUPY WYSOKIEGO RYZYKA: ANALIZA NA PODSTAWIE 3-LETNIEGO BADANIA PRZEPROWADZONEGO WE WŁOSKIM SZPITALU}

\section{Streszczenie}

Tło: Dane Światowej Organizacji Zdrowia (WHO) z 2013 r. wskazują, że blisko 360 milionów ludzi posiada wady słuchu, z czego 32 miliony to dzieci. Główną konsekwencją niedosłuchu są problemy w komunikacji: obserwuje się opóźniony rozwój języka mówionego u dzieci z niedosłuchem, lub jego brak w przypadku całkowitej głuchoty. Dzieci takie mogą korzystać z różnych form wspomagających, np. aparaty słuchowe, implanty ślimakowe, pomoce naukowe i wsparcie społeczne. Badania przesiewowe 
słuchu mają zadanie zapobiec poważnym konsekwencjom związanym z niedosłuchem. W pierwszej kolejności zalecane jest jednak wyłonienie populacji szczególnie zagrożonych zaburzeniami słuchu. Celem niniejszego badania była ocena występowania zaburzeń słuchu za pomocą rejestracji słuchowych potencjałów wywołanych (ABR) u noworodków w grupie wysokiego ryzyka, przebywających w szpitalu Casa Sollievo della Sofferenza w południowych Włoszech.

Materiał i metody: Praca przedstawia wyniki rejestracji słuchowych potencjałów wywołanych uzyskane w okresie 3 lat u niemowlaków z zespołem zaburzeń oddychania (IRDS), nieprawidłowym wynikiem badania przesiewowego za pomocą rejestracji emisji otoakustycznych (OAE), niską masa urodzeniową (<1800 g), hiperbilirubinemią, infekcjami wrodzonymi (cytomegalowirus - CMV), deformacjami czaszkowo-twarzowymi, a także u wcześniaków oraz w przypadkach występowania głuchoty w rodzinie.

Wyniki: Spośród 549 badanych noworodków, u 469 (85,4\%) stwierdzono normalny słuch, 51 99,3\%) miało lekki niedosłuch, u $6(1,1 \%)$ stwierdzono niedosłuch średniego, a u 8 (1,5\%) - znacznego stopnia, natomiast u 15 (2,7\%) obustronnie nie zarejestrowano odpowiedzi ABR. Dla wymienionych kategorii niedosłuchu, najważniejszymi czynnikami zagrażającymi (w kolejności od najczęstszego) okazały się: deformacje czaszkowo-twarzowe, zakażenie CMV oraz uwarunkowania genetyczne.

Wnioski: Banie słuchowych potencjałów wywołanych pnia mózgu jest ważnym narzędziem klinicznym w wykrywaniu oraz określaniu stopnia niedosłuchu. Podczas prowadzenia badań przesiewowych u noworodków, w pierwszej kolejności zaleca się określenie grupy osób szczególnie narażonych na wystąpienie wad słuchu.

Słowa kluczowe: słuchowe potencjały wywołane pnia mózgu $(\mathrm{ABR}) \bullet$ emisja otoakustyczna $(\mathrm{OAE}) \bullet$ oddział intensywnej terapii dla noworodków $(\mathrm{NICU}) \cdot$ niedosłuch

\section{Background}

The most frequent sensorial congenital defect in newborns is neonatal hearing loss. WHO considers neonatal hearing loss (HL) to be a serious public health problem requiring urgent attention [1-10]. It is estimated that approximately $80 \%$ of all sensorineural hearing losses (SNHLs) may be present at or soon after birth [2]. WHO reported in 2013 that approximately 360 million people have disabling hearing loss of which 32 million are children. The prevalence of hearing loss in developed countries is $1-2 / 1000$ births [2].

A large number of studies among Italian newborns [3] show a highly variable prevalence ranging from 0.8 to 2.1 per 1000. Considering the small number of newborns undergoing neonatal hearing screening, which currently covers approximately $29.3 \%$ of babies born in Italy, the prevalence of hearing loss cannot be estimated correctly. Studies in neonates in neonatal intensive care units (NICUs) report estimates as high as $4 \%$ of the total neonatal population $[4,5]$. The importance of early detection and rehabilitation of infants with hearing impairment cannot be overstated. Unfortunately, the average time between birth and the detection of congenital SNHL can be as long as 30 months.

Risk factors for the development of hearing loss were established in 2007 by the Joint Committee on Infant Hearing (JCIH) [6]. These include: family history, craniofacial anomalies, in utero infections, severe hyperbilirubinemia, NICU admission for 2 days, respiratory distress, prolonged mechanical ventilation, and syndromes associated with hearing loss.

When screening neonatal hearing, it is best to first consider populations who have a higher probability of developing a hearing impairment. The risk-factor criteria proposed by the JCIH $[7,8]$ are very useful for identifying this category of subjects. Moreover, hearing loss in its undetected mild and moderate forms can also compromise speech abilities [9]. Today, early detection of permanent infant hearing impairment is important, since appropriate procedures involving hearing aids and rehabilitation can be taken to ensure better language development and cognitive function $[10,11]$.

Young patients with syndromic hearing losses or multiple handicaps can benefit from a range of interventions such as cochlear implants, hearing aids, sign language training, and educational and social support [12]. Data in the literature suggest that large numbers of children with hearing loss, who need help and counselling, reside in developing countries where there is an alarming paucity of ENT specialists, audiologists, and speech therapy services [13].

A major responsibility therefore rests with the local audiologist or clinical medical officer to diagnose hearing loss, to counsel parents and teachers, and to provide rehabilitation [14]. In developed countries, children with hearing loss and deafness often miss out on normal schooling. Improving access to education and speech rehabilitation services, and raising awareness of hearing handicaps, especially among employers, would tend to reduce unnecessarily high unemployment rates among hearing impaired adults. Early detection and intervention are the most important ways of minimising the impact of hearing loss on a child's development and education. ABR is considered the most sensitive method of assessing the hearing function of neonates [15], and is an important clinical tool in identifying and quantifying hearing impairment. It is objective, non-invasive, and unaffected by sleep or drugs.

Unfortunately, it has been reported that about $50 \%$ of the infantile cases identified as having a hearing impairment do not show any of the JCIH factors $[7,8]$. Therefore, a screening program using only otoacoustic emissions (OAEs) could potentially miss an important percentage of cases presenting retrocochlear hearing complications, i.e. auditory neuropathy [16-18].

The aim of this study was to investigate the incidence of neonatal deafness in the neonatal intensive care unit 
(NICU) of the Casa Sollievo della Sofferenza Hospital, a major hospital in southern Italy, and assess the risk categories of hearing loss.

\section{Material and methods}

A total of 549 infants (285 male, 264 female) from the NICU were tested between September 2010 and September 2013. For each infant, the following information was collected: gestational age, family history of hearing loss, asphyxia, respiratory distress syndrome (RDS), craniofacial malformation, otoacoustic emission outcome, and neonatal jaundice. The infants were tested during natural sleep.

An otoscopic examination and tympanometry were performed prior to testing in order to exclude middle and retrocochlear hearing loss involvement.

Each ear was assessed separately by an ABR using the Epic equipment (Labat, SRL, Italy). Electrodes were placed on the vertex $(\mathrm{Cz}$, positive electrode), both mastoids, and on the forehead (ground). Responses were filtered with a band pass of 100 to $2500 \mathrm{~Hz}$. The analysis window was $10 \mathrm{~ms}$. Stimuli consisted of $100 \mathrm{~ms}$ alternating clicks presented monaurally at 31/s. An average of at least 1000 individual click presentations was collected for each test stimulus level. The clicks were presented to the infant ear via TDH 39 earphones.

A response was considered normal when a clear and reproducible wave $\mathrm{V}$ was detected at an intensity of $20 \mathrm{~dB}$ $\mathrm{nHL}$. In the case of a lack of response at $70 \mathrm{~dB} \mathrm{nHL}$, the stimuli were increased to a maximum level of $90 \mathrm{~dB} \mathrm{nHL}$.

Infants who failed the first test (unilateral cases included) were retested after 1-2 months. Considerable effort was made to retest all high-risk infants at 3-4 months of age. Infants were identified as having a hearing impairment after two consecutive 'refer' ABR sessions. Subsequent hearing aid evaluation, medical treatment, and enrollment in a speech therapy program were recommended.

For infants who presented with normal hearing at birth the protocol suggested a periodic hearing control (every 6 months), if possible, until the sixth year of age.

A medical summary was compiled for each child, including the age of hearing impairment diagnosis, the level of hearing loss, and information on the following risk factors: 1. Infantile respiratory distress syndrome (IRDS).

2. Otoacoustic emissions outcome at hearing screening testing.

3. Low birth weight $(<1800 \mathrm{~g})$.

4. Family history of deafness.

5. High level of bilirubin.

6. Premature birth.

7. Congenital infection (cytomegalovirus).

8. Craniofacial malformation.

\section{Degree and configuration of hearing loss}

The grade of hearing loss was quantified for each ear as an indication of the severity of hearing impairment, according to the Table 1.
Table 1. Grading of hearing loss

\begin{tabular}{cl}
\hline Grade & \multicolumn{1}{c}{ Level in $\mathbf{d B} \mathbf{n H L}$} \\
\hline Normal & Threshold up to $30 \mathrm{~dB}$ and below \\
\hline Mild & Threshold between 30 to $60 \mathrm{~dB}$ \\
\hline Moderate & Threshold between 60 to $70 \mathrm{~dB}$ \\
\hline Severe & Threshold between 70 to $90 \mathrm{~dB}$ \\
\hline Profound & Threshold above $90 \mathrm{~dB}$ \\
\hline
\end{tabular}

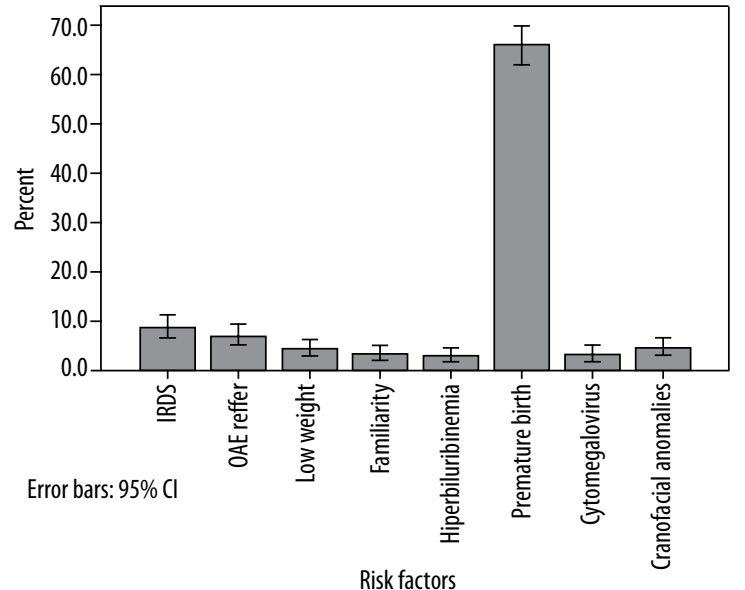

Figure 1. Risk factor distribution of the infants in the tested population

\section{Statistical analysis}

The hearing level values were statistically described in terms of the mean, minimum and maximum values, standard deviations, and percent using SPSS 16.0 statistical software.

\section{Results}

\section{Clinical characteristics of the studied population}

The population sample consisted of 285 males (51.9\%) and 264 females (48.1\%). Of the 549 infants tested, 362 $(65.9 \%)$ were born pre-term ( $<37$ weeks), the most prominent risk factor. In addition, 48 (8.7\%) presented infantile respiratory distress syndrome (IRDS) at birth, 38 (6.9\%) did not pass OAE screening, $24(4.4 \%)$ presented a low birth-weight $(<1800 \mathrm{~g}), 18(3.3 \%)$ had a family history of deafness, 16 (2.9\%) presented a high level of bilirubin (neonatal jaundice), 18 (3.3\%) had cytomegalovirus infection (congenital infection), and 25 (4.6\%) presented craniofacial malformation at birth. These data are summarised in Figure 1.

Of the 362 infants born premature, the average gestational age was 33 weeks (median 34 weeks, range 23-38 weeks). Figure 2 shows the distribution of the gestational ages among the premature infants.

Of the 549 infants tested, 469 (85.4\%) showed normal hearing, 51 (9.3\%) suffered mild hearing impairment, 6 (1.1\%) 


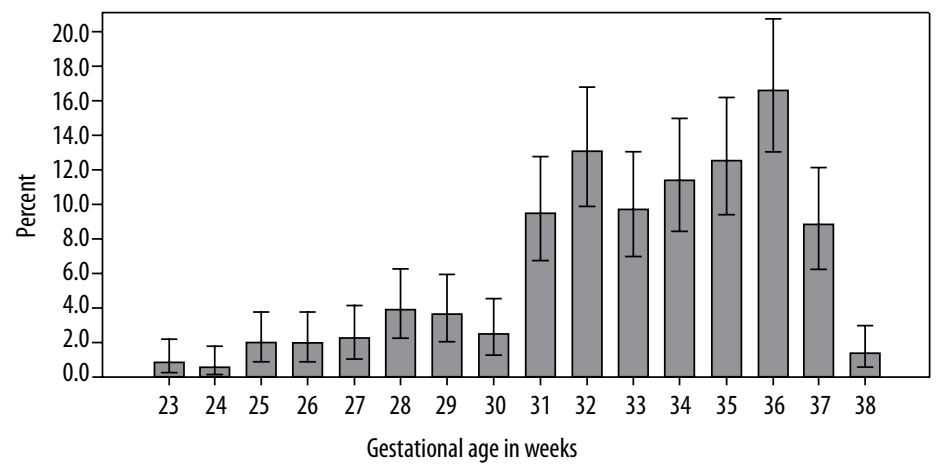

Figure 2. Distribution of gestational age (in weeks) of the 362 tested premature infants. Error bars $95 \% \mathrm{Cl}$

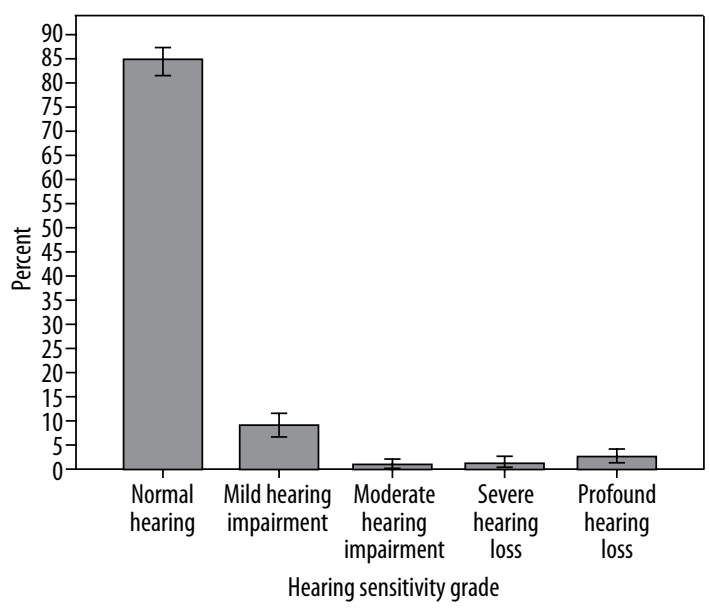

Figure 3. Distribution of hearing loss in the tested population. Error bars $95 \% \mathrm{Cl}$

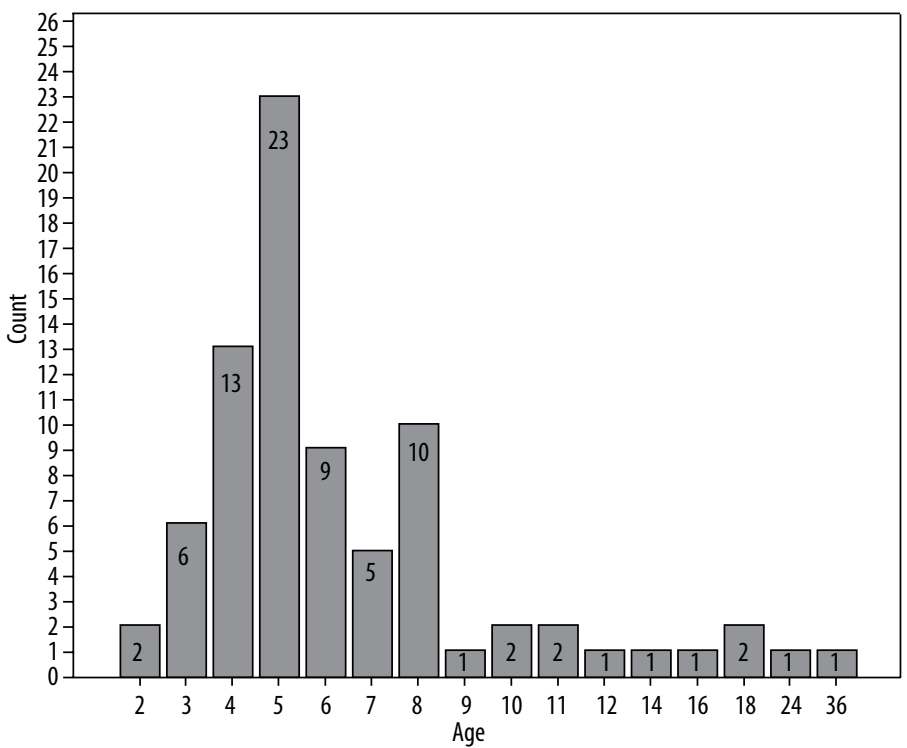

presented moderate hearing impairment, 8 (1.5\%) presented severe hearing loss and 15 (2.7\%) didn't show any response at maximum intensity levels in either ear. The data are summarised in Figure 3.

The distribution of the ages at which the 80 infants were identified as having a hearing impairment is shown in Figure 4 . The data shows that $92.7 \%$ of the subjects were identified $\leq 12$ months of age, $4,9 \%$ between 13 and 18 months, and the remaining $2,4 \%$ at a time more than 18 months. Data beyond the 18-month identification age derive from 2 infants whose families were not residents of the San Giovanni Rotondo area. In this context, it is quite probable that in the future infants from non-resident families will not be tested and clinically evaluated.

For the hearing loss categories the most important risk factors were found to be (in order of importance): craniofacial malformation, CMV infection, and family factors. The data are summarised in Figure 5.

Figure 6 shows the ABR threshold of the premature newborns according to their gestational age at birth. Risk of hearing loss increases dramatically when the gestational age is less than 30 weeks.

Figure 4. Age in months of the 80 infants from the tested NICU population when they were identified as having a hearing impairment 


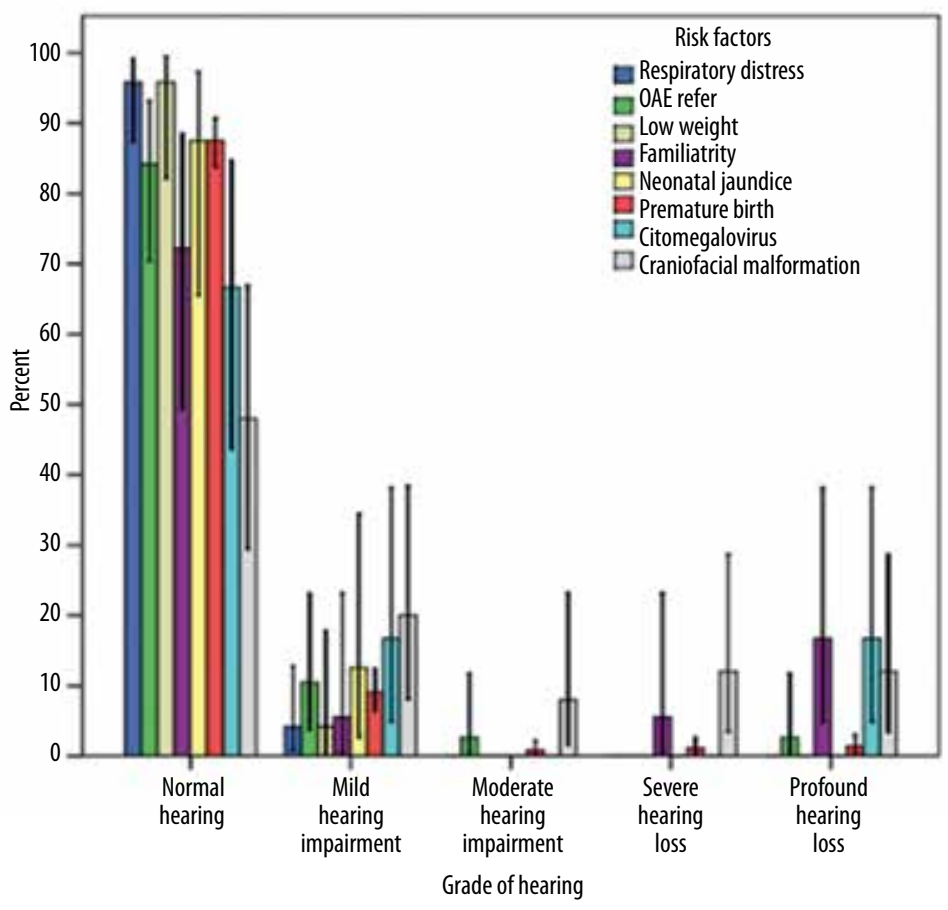

Figure 5. Risk factors in each hearing level category among the tested NICU population. Error bars $95 \% \mathrm{Cl}$

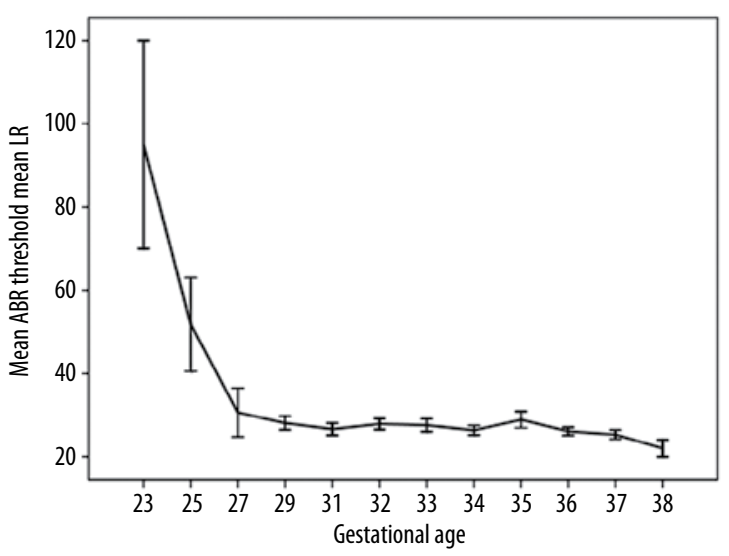

Figure 6. $A B R$ threshold distribution in the premature birth category according to gestational age (in weeks). Error bars show $\pm 1 \mathrm{SE}$

In $84.2 \%$ of the cases with OAEs absent, the ABR was found normal. For the $15.8 \%$ of cases with OAEs absent, the ABR confirmed the presence of hearing loss, mainly as a mild hearing impairment. The data are summarised in Figure 7.

\section{Discussion}

We have demonstrated how the incidence of hearing loss (HL) increases in a high-risk newborn population and how ABR testing is a necessary technique, in addition to the traditional NHS OAE procedure, to confirm neonatal hearing impairment. ABR is an important tool in identifying hearing impairment in neonates, and is not affected by external ear wax or fluid and has high sensitivity and specificity. It is important to first test populations with high

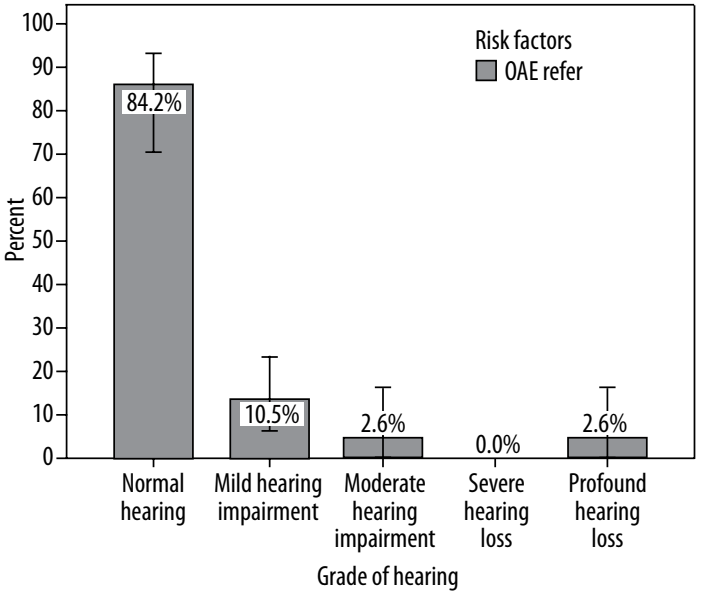

Figure 7. Correlation between OAE results and hearing loss confirmed by ABR. Error bars $95 \% \mathrm{Cl}$

probabilities of developing hearing impairment. Various tools are available to detect the majority of children who have a hearing disorder, and both OAE and ABR have now been tested in various centers.

The incidence of hearing loss differs between studies. The JCIH have suggested that hearing screening should be done in all neonates whether or not they are high risk; $\mathrm{JCIH}$ also recommend reevaluating the hearing of neonates after 3 months if they fail the initial screening test [7]. All babies should be screened at birth. If the result of screening fails, complete hearing tests several weeks after birth should be done.

ABR should be used in all screening programs to distinguish children with hearing impairment from those with 
normal hearing who register a false positive result. Although OAE screening is quicker and easier to perform than ABR it is affected by external ear wax or fluid. Sometimes, in various studies, the OAE test is performed twice $[18,19]$. OAE and ABR together are a valid combination for use in universal newborn hearing screening.

\section{Conclusions}

The present study was done to show the incidence of hearing impairment through $\mathrm{ABR}$ in infants at high risk at Casa Sollievo della Sofferenza Hospital. Hearing screening is the key to prevent the most severe consequences of hearing loss. In neonatal screening, it is preferable to first consider populations with high probabilities of developing a hearing impairment. In our study we found that of 549 infants tested, 469 (85.4\%) showed normal hearing, 51 (9.3\%) suffered mild hearing impairment, 6 (1.1\%) moderate hearing impairment, 8 (1.5\%) had severe hearing loss, and $15(2.7 \%)$ did not show any response at maximum intensity levels in both ears (profound hearing loss).

These results show the importance of early diagnosis of hearing loss, and we advise use of ABR as a screening tool for patients at risk of hearing loss.

\section{References:}

1. Van Dyke DC, Holte L. Communication disorders in children. Pediatric Annals, 2003; 32(7): 436.

2. World Health Organization. WHO: Deafness and hearing loss, Fact sheet No. 300, updated February 2013.

3. Bubbico L, Rosano A, Spagnolo A. Prevalence of prelingual deafness in Italy. Acta Otorhinolaryngol Ital, 2007; 27(1): $17-21$.

4. Mauk GW, White KR, Mortensen LB, Behrens TR. The effectiveness of screening programs based on high-risk characteristics in early identification of hearing impairment. Ear Hearing, 1991;12: 312-9.

5. Gerber S. Review of a high-risk register for congenital or early onset deafness. Br J Audiol, 1990; 24: 347-56.

6. Paludetti G, Conti G, Di Nardo W, De Corso E, Rolesi R, Picciotti PM et al. Infant hearing loss: from diagnosis to therapy. Official Report of XXI Conference of Italian Society of Pediatric Otorhinolaryngology. Acta Otorhinolaryngol Ital, 2012; 32(6): 347-70.

7. Joint Committee on Infant Hearing. 1990 position statement. ASHA, 1991; 33: 3-6.

8. Mauk GW, White KR, Mortensen LB, Beherens TR. The effectiveness of hearing programs based on high-risk characteristic in early intervention of hearing impairment. Ear Hear, 1991; 12: 312-9.

9. Downs MP, Yoshingata-Itano C. The efficacy of early intervention for children with hearing impairment. Pediatr Clin North Am, 1999; 46(1): 79-87.

10. Moeller MP. Early intervention and language development in children who are deaf and hard of hearing. Pediatrics, 2000; 106: $43-51$.
11. Molini E, Ricci G, Baroni S, Ciorba A, Bellocci A, Simoncelli C. Identifying congenital hearing impairment. Personal experience based on selective hearing screening. Acta Otorhinolaryngol Ital, 2004; 24: 109-16.

12. Sampathkumar R, Ravikumar A, Kameswaran M, Mandke K, Ranjith R. Clinical application of a multimodal electrophysiological test battery to predict optimal behavioral levels in cochlear implantees. J Hear Sci, 2013; 3(4): OA31-48.

13. Olusanya BO, Newton VE. Global burden of childhood hearing impairment and disease control priorities for developing countries. Lancet, 2007; 369: 1314-7.

14. Johansson, B, Olsson L. Open access guide to audiology and hearing aids for otolaryngologists. Newborn and infant hearing screening. www.entdev.uct.ac.za/guides/open-access-guideto-audiology-and-hearing-aids-for-otolaryngologists

15. van Straaten HLM, Groote ME, Oudesluys-Murphy AM. Evaluation of an automated auditory brainstem response infant hearing screening method in at risk neonates. Eur J Pediatr, 1996; 155: 702-5.

16. Hatzopoulos S, Petruccelli J, Pelosi G, Martini A. An optimized neonatal TEOAE screening protocol based on linear stimulus sequences. Acta Otolaryngol (Stockh), 1999; 119: 135-9.

17. Hatzopoulos S, Petruccelli J, Ciorba A, Martini A. Optimizing otoacoustic emission protocols for a UNHS program $\mathrm{Au}-$ diol Neurotol, 2009; 14(1): 7-16.

18. Ciorba A, Hatzopoulos S, Busi M, Petruccelli J, Martini A. The universal newborn hearing screening program at the University Hospital of Ferrara: Focus on solutions and pitfalls. Int J Pediatr Otorhinolaryngol, 2008; 72(6): 807-16

19. Yousefi J, Ajalloueyan M, Amirsalari S, Hassanali Fard M. The specificity and sensitivity of transient otoacoustic emission in neonatal hearing screening compared with diagnostic test of auditory brain stem response in Tehran hospitals. Iranian J Pediatr, 2013; 23: 199-204. 